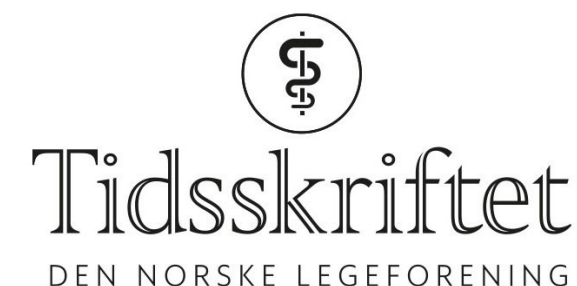

\title{
Rettelse: Bruk av ciprofloksacin ved et lokalsykehus
}

RETTELSE

VIGDIS ANDREASSEN

BJØRN WAAGSB $\varnothing$

HEGE SALVESEN BLIX

Tidsskr Nor Legeforen 2020; 140: 1463-5.

I Tidsskriftet nr. 14/2020, s. 1463 og 1465 skal forfatterrekkefølgen være:Vigdis Andreassen, Bjørn Waagsbø, Hege Salvesen Blix.

Vi beklager feilen, den er rettet på nett.

Publisert: 15. oktober 2020. Tidsskr Nor Legeforen. DOI: 10.4045/tidsskr.20.o8o9

(C) Tidsskrift for Den norske legeforening 2020. Lastet ned fra tidsskriftet.no 